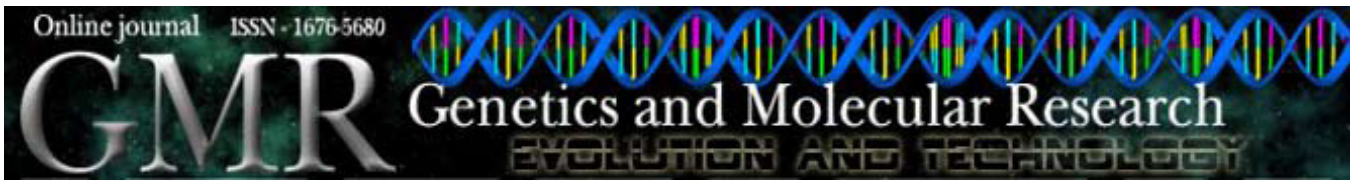

\title{
SSR analysis demonstrates that olive production in the southern Marmara region in Turkey uses a single genotype
}

\author{
A. Ipek ${ }^{1}$, E. Barut ${ }^{1}$, H. Gulen ${ }^{1}$, A.T. Oz ${ }^{2}$, N.A. Tangu ${ }^{3}$ and M. Ipek ${ }^{1}$ \\ ${ }^{1}$ Uludag University, Faculty of Agriculture, Horticulture Department, \\ Gorukle, Bursa, Turkey \\ ${ }^{2}$ Atatürk Central Horticultural Research Institute, Yalova, Turkey \\ ${ }^{3}$ Kahramanmaras Agricultural Research Institute, Kahramanmaras, Turkey \\ Corresponding author: A. Ipek \\ E-mail: maipek@uludag.edu.tr
}

Genet. Mol. Res. 8 (4): 1264-1272 (2009)

Received July 16, 2009

Accepted August 11, 2009

Published October 20, 2009

\begin{abstract}
The southern Marmara region in Turkey was surveyed to determine the olive cultivars that are used for olive production. Genetic diversity analysis using simple sequence repeat (SSR) markers indicated that the cultivar Gemlik is the major olive cultivar grown in this region, while other olive cultivars are grown only for use as pollinators of Gemlik or for growers' own exotic consumption. Although the quality of Gemlik is widely accepted in Turkey, its tendency toward alternate bearing is a major drawback. Twentyfour genotypes were selected within the cultivar Gemlik because of their tolerance to alternate bearing. These selected genotypes have the same SSR alleles as Gemlik, making them good candidates for developing a Gemlik olive with reduced alternate bearing. About $8 \%$ of samples did not share the same SSR alleles with Gemlik, though these genotypes were identified as Gemlik by the growers.
\end{abstract}


Some other standard cultivars that are grown in other regions of Turkey were mistakenly called Gemlik in this region, probably due to the popularity of this cultivar in the southern Marmara region. In conclusion, as indicated by SSR analysis, Gemlik has become the standard cultivar in this region; future research should be focused on techniques to improve the production and quality of table olives and olive oil from this cultivar.

Key words: Olive; Olea europaea; Molecular markers; Simple sequence repeat markers

\section{INTRODUCTION}

Olive (Olea europaea L.) is one of the most economically important fruit tree species in the Mediterranean basin, whose domestication goes back 6000 years in the area bordering the east coast of the Mediterranean (Sensi et al., 2003). Historically, table olives and olive oil have been an important part of the Mediterranean diet, and currently, olives have been consumed as table olives and olive oil worldwide. The Mediterranean region (Spain, Italy, Greece, Turkey, Tunisia, Morocco, Syria, and Portugal) is the major production area, accounting for more than $90 \%$ of world production (FAO, 2007). Turkey is the fourth biggest olive-producing country in the world and is ranked fifth in olive oil and second in table olive production. Most of the olive production in Turkey occurs in the Aegean, Marmara and Mediterranean regions (Mendilcioglu, 2001). Although most of the table olives consumed are black table olives, green and kalamata type table olives are also available in Turkey (Ünal and Nergiz, 2003). In addition to olive consumption as table olives, olive oil has been an economically important commodity for both domestic consumption and export.

Olive production in the world uses more than 1275 cultivars (Bartolini et al., 1998), and most of these cultivars have been identified in European countries including 538 in Italy, 183 in Spain, 88 in France, and 52 in Greece (Sarri et al., 2006). In Turkey, 88 local olive cultivars have been used for olive production (Aktan and Kalkan, 1999). The long lifespan of olive trees, ability of olive trees to survive for a long time without cultivation and slower turnover with new genotypes than other fruit crops have made olives resistant to genetic erosion and loss of biodiversity (Angiolillo et al., 1999; Sensi et al., 2003; Sarri et al., 2006). This has resulted in an increase in the number of cultivars used for commercial olive production.

Traditionally, morphological and phenological characters have been used for cultivar identification in olive (Fabbri et al., 1995). However, olive, as an out-crossing crop species, shows continuous variation and high plasticity for most of its morphological, physiological and biochemical traits. In addition, most of such traits can be easily affected by environmental factors and plant age. Moreover, the simultaneous presence of local and patchy-distributed cultivars with ambiguous naming and continuous interchange of plant materials among the different olive production regions and countries have complicated cultivar identification, resulting in a confusing pattern of geographic distribution of cultivars (Sarri et al., 2006).

It has been indicated that cultivars are important for olive oil yield and quality 
(Sanz-Cortés et al., 2003), as is true also for table olive production. In Turkey, olive production has involved the use of many local olive cultivars, which makes standardized olive and olive oil production for marketing very difficult. The identification of superior genotypes adapted to major olive production regions in Turkey can provide an opportunity for standardized olive oil and table olive production and consequently for better marketing. Therefore, the purpose of this study was to 1) analyze genetic diversity among the olive genotypes maintained in the Atatürk Central Horticultural Research Institute, Yalova and 2) identify olive genotypes used for olive production in the southern Marmara region of Turkey by comparing them with the olive genotypes maintained in the Atatürk Central Horticultural Research Institute, Yalova, using simple sequence repeat (SSR) markers. SSR markers have been developed for olive by several groups (Sefc et al., 2000; Carriero et al., 2002; Cipriani et al., 2002), and this marker system was found to be the most reliable, effective and easy-to-use for identification of olive cultivars (Sarri et al., 2006).

\section{MATERIAL AND METHODS}

\section{Plant materials}

In this study, the genetic relationship between 14 olive cultivars and 24 selected olive genotypes kept in the Atatürk Central Horticultural Research Institute, Yalova, was analyzed (Table 1). These 24 selected genotypes have been identified within the cultivar Gemlik in the southern Marmara region in Turkey, and they have been selected on the basis of their tolerance to alternate bearing (Yalcinkaya et al., 2000). In addition, 10 major olive production locations in the southern Marmara region were surveyed for olive cultivars grown for commercial olive production (Figure 1). Olive trees in the production orchards were sampled for DNA extraction, and the names of cultivars given by the growers who own the orchards were recorded (Table 2). A total of 51 leaf samples from these 10 locations were collected.

\begin{tabular}{|c|c|c|}
\hline \multirow{2}{*}{$\begin{array}{l}\text { Olive cultivars } \\
\text { Büyük Topak Ulak }\end{array}$} & \multicolumn{2}{|c|}{ Selected genotypes } \\
\hline & O-9 & G-20/8 \\
\hline Domat & $\mathrm{O}-12$ & $\mathrm{I}-2 / 1$ \\
\hline Edincik Su & $\mathrm{O}-24$ & I- $-15 / 3$ \\
\hline Gemlik & G-2/1 & I- $18 / 3$ \\
\hline Hojiblanca & $\mathrm{G}-4 / 3$ & $\mathrm{M}-2 / 3$ \\
\hline Kan Zeytini & G-10/1 & $\mathrm{M}-4 / 3$ \\
\hline Karamürsel Su & G-12/2 & $\mathrm{M}-12 / 1$ \\
\hline Meski & G-12/3 & $\mathrm{M}-12 / 2$ \\
\hline Manzanilla & G-12/7 & M-16/1 \\
\hline Samanlı & G-20/1 & M-16/2 \\
\hline Tavşan Yüreği & G-20/3 & \\
\hline Uslu & G-20/5 & \\
\hline Yuvarlak Halhal & G-20/6 & \\
\hline Ascolana & G-20/7 & \\
\hline
\end{tabular}




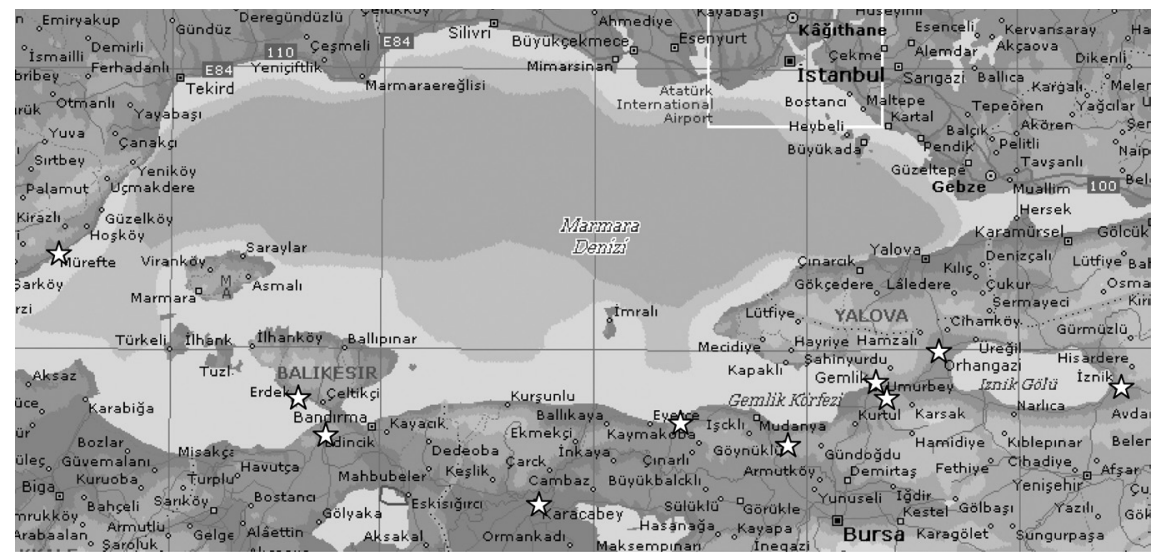

Figure 1. Map of the southern Marmara region. Stars show the sites where samples were collected.

Table 2. Locations and the number of Gemlik samples collected in the southern Marmara region in Turkey.

\begin{tabular}{lc}
\hline Locations & Number of samples \\
\hline Göynüklü & $4(1)$ \\
Zeytinbagi & 4 \\
Umurbey & $6(1)$ \\
Gemlik & 6 \\
Orhangazi & 5 \\
Iznik & $3(1)$ \\
Edincik & 1 \\
Erdek & $7(1)$ \\
Mürefte & 9 \\
Karacabey & 6 \\
Total & 51 \\
\hline
\end{tabular}

The number in parentheses indicates the number of genotypes with different SSR marker alleles from the cultivar Gemlik.

\section{DNA extraction}

Young leaves of olive trees were sampled for DNA extraction. Lyophilized leaf samples were ground to a fine powder using a mortar and pestle. DNA samples were extracted from $150 \mathrm{mg}$ powdered leaf samples using a modified CTAB method described by Fütterer et al. (1995). The phenol:chloroform (1:1, v/v) extraction method of DNA was used to increase purity of DNA for SSR analysis. The concentrations of each DNA sample were measured using a Qubit Fluorometer (Invitrogen, Carlsbad, CA, USA) and adjusted to $50 \mathrm{ng} / \mu \mathrm{L}$ for analysis.

\section{SSR analysis}

Ten previously developed SSR primers were used for amplification of SSR markers in this study (Table 3). Each 20- $\mu \mathrm{L}$ polymerase chain reaction (PCR) mixture for amplification of SSR markers consisted of 0.75 U DNA polymerase (Fermentas, Hanover, MD, USA) with the reaction buffer supplied at $1 \mathrm{X}$ concentration, $0.4 \mathrm{mM}$ of each primer, dNTPs at $0.25 \mathrm{mM}$ each, 
and $50 \mathrm{ng}$ template DNA. Thermal cycling conditions were: 2 min at $94^{\circ} \mathrm{C} ; 10$ cycles of $45 \mathrm{~s}$ at $94^{\circ} \mathrm{C}, 1 \mathrm{~min}$ at $65^{\circ} \mathrm{C}$ (annealing temperature was reduced $1^{\circ} \mathrm{C}$ after every cycle), and $1 \mathrm{~min}$ and $30 \mathrm{~s}$ at $72^{\circ} \mathrm{C} ; 35$ cycles of $45 \mathrm{~s}$ at $94^{\circ} \mathrm{C}, 1 \mathrm{~min}$ at $55^{\circ} \mathrm{C}$, and $1 \mathrm{~min}$ and $30 \mathrm{~s}$ at $72^{\circ} \mathrm{C}$, and a final extension step of $5 \mathrm{~min}$ at $72^{\circ} \mathrm{C}$. An Applied Biosystems Thermal Cycler was used for these reactions. PCR products were separated on a $4 \%$ agarose SFR ${ }^{\mathrm{TM}}$ gel (Amresco Inc., Solon, OH, USA) in $1 X$ Tris-borate buffer. Gels were stained with ethidium bromide $(0.5 \mathrm{mg} / \mathrm{mL}$; Sigma, St Louis, MO, USA) and photographed.

\begin{tabular}{lc}
\multicolumn{2}{c}{ Table 3. List of SSR primers and number of their polymorphic alleles. } \\
\hline Marker name & Number of polymorphic alleles \\
\hline GAPU103 A & 5 \\
GAPU101 & 4 \\
UDO99-006 & 3 \\
UDO99-007 & 4 \\
UDO99-009 & 3 \\
UDO99-011 & 2 \\
UDO99-012 & 2 \\
UDO99-014 & 3 \\
UDO99-015 & 5 \\
UDO99-035 & 5 \\
Total & 36 \\
\hline
\end{tabular}

GAPU and UDO99 primers were developed by Carriero et al. (2002) and Cipriani et al. (2002), respectively.

\section{Data analysis}

SSR markers were scored as present (1) or absent (0) since allelic constitution of these SSR markers was not known in the plant materials studied. Simple matching similarity coefficients (Sneath and Sokal, 1973) were calculated for all pair-wise comparisons among 14 olive cultivars and 24 selected olive genotypes. A dendrogram demonstrating the relative genetic relationship was generated using NTSYSpc version 2.11V (Exeter Software, Setauket, NY) (Rohlf, 2004) based on the unweighted pair-group method of arithmetic mean cluster analysis (UPGMA). Fifty-one olive cultivars whose samples were collected from the southern Marmara region were not included in the cluster analysis but their allelic patterns of SSR markers were compared with those of common cultivars held in the Atatürk Central Horticultural Research Institute, Yalova.

\section{RESULTS AND DISCUSSION}

\section{SSR polymorphism and its discriminating power}

Ten SSR markers showed variation in their alleles among 38 olive genotypes (Figure 2). A total of 36 polymorphic alleles were identified (Table 3). The number of polymorphic alleles per SSR primer pair ranged from 2 (UDO99-011) to 5 (GAPU103 A) with an average of 3.6 polymorphic alleles per SSR primer. Previous studies also indicated a high level of SSR polymorphism in olives (Carriero et al., 2002; Sarri et al., 2006; Muzzalupo et al., 2006; 
Gomes et al., 2008). This degree of polymorphism is comparable to that reported by Cipriani et al. (2002) and Gomes et al. (2008), but it is somewhat lower than that found by Carriero et al. (2002), Sarri et al. (2006) and Muzzalupo et al. (2006). This high level of polymorphism in the alleles of SSR markers confirms that genetically diverse olive cultivars have been used in olive production in Turkey and in the world. This high genetic variation can be useful for breeding programs but it can pose a problem for standardized table olive and olive oil production.

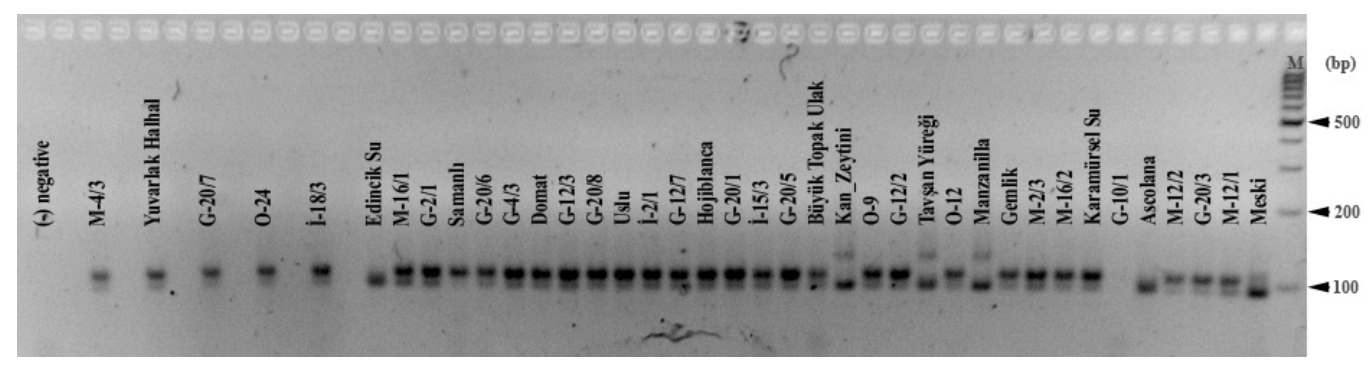

Figure 2. Agarose gel showing alleles of UDO99-014 SSR markers among 14 olive cultivars and 24 selected genotypes.

SSR markers were found to be an effective marker system for discriminating olive genotype in this study, and 10 SSR markers were enough to discriminate genetically distinct olive cultivars. Similarly, Sarri et al. (2006) also found SSR markers the most reliable, effective and easy-to-use markers for detecting genetic polymorphism among olive cultivars. In previous studies, polyacrylamide gel and DNA sequencing systems with fluorescent labeling were used for detecting polymorphic alleles of SSR markers (Carriero et al., 2002; Sarri et al., 2006; Gomes et al., 2008). While the use of polyacrylamide gel is a labor-intensive task, DNA sequencing systems are a high-cost analysis system and may not be available to every investigator. In this study, we used high-resolution agarose gel electrophoresis ( $4 \%$ agarose $\mathrm{SFR}^{\mathrm{TM}}$ ) to detect SSR polymorphisms among olive genotypes, and the level of polymorphism detected in this study is comparable to previous studies of Cipriani et al. (2002) and Gomes et al. (2008). For future studies, we recommend the use of high-resolution agarose gels to detect SSR polymorphisms in olive since it can decrease cost and labor without losing the discriminating power of the SSR marker system.

\section{Genetic relationship between olive genotypes}

Genetic similarity among 14 olive cultivars, and 24 selected genotypes calculated using simple matching coefficient ranged from 0.41 to 1.00. A UPGMA dendrogram demonstrating the genetic relatedness among the 38 genotypes using a similarity matrix was developed (Figure 3). According to the dendrogram, 4 groups were determined to be above $60 \%$ similarity. In group I, the cultivars Gemlik, Uslu, Büyük Topak Ulak, Domat, and Yuvarlak Halhal clustered along with 24 selected genotypes. Kan Zeytini, Ascolana and Meski clustered together in group II while local cultivars Edincik Su and Tavşan Yüreği 
grouped together with Manzanilla in group III. Group IV was composed of Samanl1, Karamürsel Su and Hojiblanca (Figure 3).

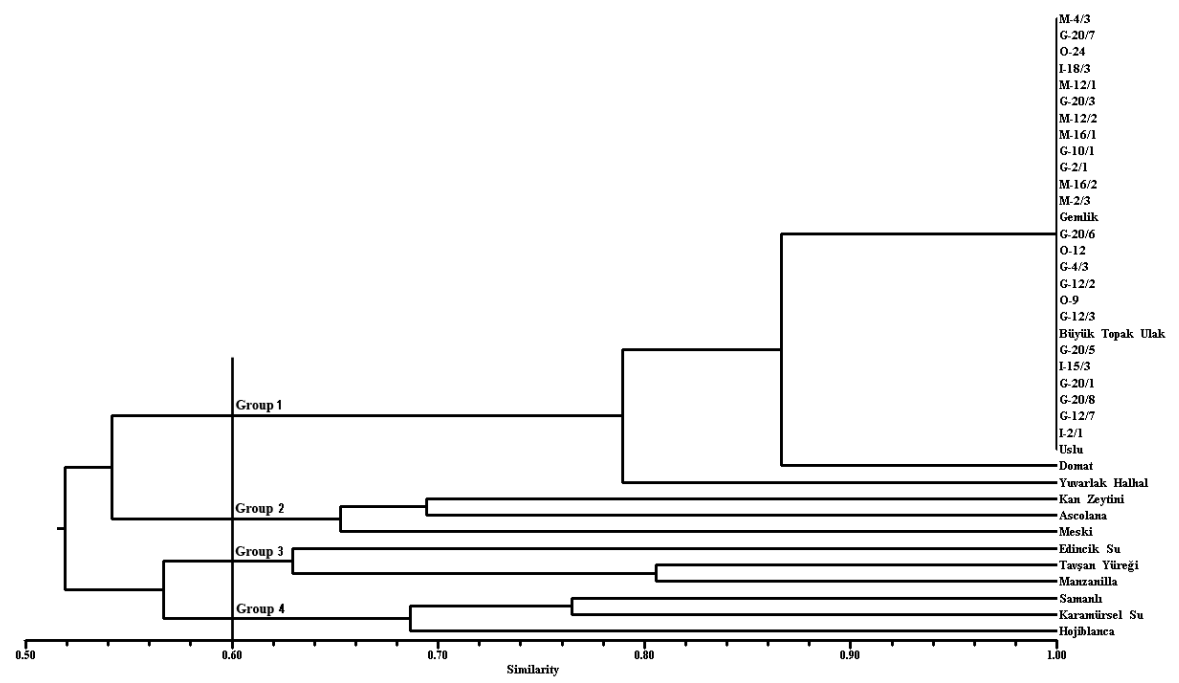

Figure 3. UPGMA dendrogram showing the estimated genetic relationships between 14 olive cultivars and 24 selected genotypes.

In group I, local cultivars Uslu and Buyuk Topak Ulak shared $100 \%$ of the SSR alleles with the cultivar Gemlik (Figure 3), suggesting that they may be genetically the same genotypes. Uslu and Büyük Topak Ulak are distinct cultivars from Gemlik. Büyük Topak Ulak grows widespread in the Mediterranean region of Turkey, while Uslu has been largely grown in Manisa and Izmir provinces in the Eagen Sea Region in Turkey. However, our results suggest that plants of Gemlik were mistakenly called Uslu and Büyük Topak Ulak. Therefore, this result indicates the need for the characterization of olive germplasm collections in Turkey using molecular markers.

Local and foreign cultivars were clustered together in groups II, III, and IV (Figure 3 ), suggesting that grouping genotypes based on the geographic origin are not useful in olive. Similarly, in another study, olive genotypes from different countries clustered together closely in a group (Besnard et al., 2001). The authors of that study did not find any grouping based on geographical origin of olive genotypes. This result indicates that olive genotypes have been freely exchanged among collectors in different countries for centuries. On the other hand, Sarri et al. (2006) found limited grouping on the basis of geographic origin and grouped olive cultivars as eastern, central and western Mediterranean populations.

\section{Common cultivar grown in the southern Marmara region}

The southern Marmara region is one of the major olive growing locations in Turkey. Communication with growers in this region indicated that Gemlik is the major cultivar used for 
commercial olive production in Göynüklü, Zeytinbagi, Umurbey, Gemlik, Orhangazi, Iznik, Erdek, Mürefte, and Karacabey, and that the growers only plant other cultivars or genotypes for use as pollinators for Gemlik or for their exotic consumption. However, in Edincik, another local olive cultivar, Edincik Su, is a common cultivar, although Gemlik has also been grown on a limited scale. Gemlik is one of the most important olive cultivars in the world for table olive production and it has a great economical importance in Turkey. Allelic composition of 51 Gemlik genotypes collected from the southern Marmara region has been compared with allelic composition of Gemlik cultivars kept in the Atatürk Central Horticultural Research Institute, Yalova. SSR analysis demonstrated that 47 of 51 Gemlik samples had an SSR banding profile identical to that of Gemlik plants held at the Atatürk Central Horticultural Research Institute, Yalova. Although the remaining four genotypes were called Gemlik by the growers, they had different SSR alleles compared to Gemlik. Although about $8 \%$ of the genotypes were mis-identified as Gemlik by the growers, the majority of Gemlik cultivars are identified correctly. Therefore, the results demonstrated that the cultivar Gemlik is the major cultivar grown in the southern Marmara region.

Olive has been primarily propagated by grafting seedlings, and this is a time-consuming and relatively costly propagation method. On the other hand, Gemlik can be propagated using green cuttings. Propagation using green cuttings reduces expenses, time and technical expertise needed for propagation. Therefore, the propagation of Gemlik via green cuttings has led to this cultivar becoming a major cultivar grown in this region. Gemlik cultivar has been primarily planted for black table type olive production, and it is very popular in Turkey for this purpose. However, in recent years, more olives have been produced than consumed as table olives, and therefore, Gemlik has become an important cultivar for olive oil production. This cultivar has high flesh to stone ratio, thin fruit coat, high olive oil content and high total soluble solids, and its flesh can be readily separated from the stone (Eris and Barut, 2000).

Although the fruit quality of Gemlik is widely accepted by local growers and consumers, it suffers from alternate bearing, which results in inconsistent olive production during consecutive years. Alternate bearing has also been problem for marketing olives due to the fluctuating olive supply. A study was initiated to identify variants within Gemlik, which are tolerant to alternate bearing. As a result of this study, 24 genotypes were identified by screening local olive plantations in the Mudanya, Gemlik, Orhangazi, and Iznik areas of Bursa province in the southern Marmara region in Turkey (Yalcinkaya et al., 2000). SSR analysis demonstrated that these 24 selected genotypes had identical SSR alleles and they also shared identical SSR alleles with the cultivar Gemlik in the germplasm collection, suggesting that they may be variants of Gemlik. However, we were unable to detect any genetic variation that can explain the tolerance to alternate bearing due to genetic changes in these selected genotypes. It may be very difficult to detect genetic changes such as point mutations using molecular markers such as SSR markers. It is important for the southern Marmara region to develop a Gemlik olive with tolerance to alternate bearing, and these 24 genotypes can be good candidates as plant materials in this breeding effort.

Olive oil yield and quality are largely dependent on genotypes (Sanz-Cortés et al., 2003). Therefore, it has been suggested that a standard olive oil production can be possible if a standard olive cultivar with high olive oil quality is used for production. Gemlik has become a standard olive cultivar in the southern Marmara region. Thus, this can be used as an advantage in this region to achieve standard olive oil production, in addition to its consumption as table olive. Future studies should be designed to develop techniques to increase table olive and olive oil quality produced from the cultivar, Gemlik. 


\section{ACKNOWLEDGMENTS}

Research supported by the Scientific and Technological Council of Turkey (Tübitak), Project \#105 O 071.

\section{REFERENCES}

Aktan N and Kalkan H (1999). Sofralik Zeytin Teknolojisi. Ege Üniversitesi Basimevi, Izmir.

Angiolillo A, Mencuccini M and Baldoni L (1999). Olive genetic diversity assessed using amplified fragment length polymorphisms. Theor. Appl. Genet. 98: 411-421.

Bartolini G, Prevost G, Messeri C, Carignani G, et al. (1998). Olive Germplasm: Cultivars and World-Wide Collections. FAO, Rome.

Belaj A, Satovic Z, Cipriani G, Baldoni L, et al. (2003). Comparative study of the discriminating capacity of RAPD, AFLP and SSR markers and of their effectiveness in establishing genetic relationships in olive. Theor. Appl. Genet. 107: 736-744.

Besnard G, Breton C, Baradat P, Khadari B, et al. (2001). Cultivar identification in olive based on RAPD markers J. Am. Soc. Hort. Sci. 126: 668-675.

Carriero F, Fontanazza G, Cellini F and Giorio G (2002). Identification of simple sequence repeats (SSRs) in olive (Olea europaea L.). Theor. Appl. Genet. 104: 301-307.

Cipriani G, Marrazzo MT, Marconi R, Cimato A, et al. (2002). Microsatellite markers isolated in olive (Olea europaea L.) are suitable for individual fingerprinting and reveal polymorphism within ancient cultivars. Theor. Appl. Genet. 104: 223-228.

Eris A and Barut E (2000). Iliman Iklim Meyveleri-i. Uludag Üniversitesi, Ziraat Fakültesi, Ders Kitabi No. 6, 226 s, Bursa.

Fabbri A, Hormaza JI and Polito VS (1995). Random amplified polymorphic DNA analysis of olive (Olea europaea L.) cultivars. Am. Soc. Hort. Sci. 120: 538-542.

FAO (2007). Agricultural Statistics of the Food and Agriculture Organization of the United Nations, Rome [www.FAO. org]. Accessed June 15, 2009.

Fütterer J, Gisel A, Iglesias V, Kloti A, et al. (1995). Standard Molecular Techniques for the Analysis of Transgenic Plants. In: Gene Transfer to Plants (Potrykus I and Spangenberg G, eds.). Springer-Verlag, New York, 215-218.

Gomes S, Martins-Lopes P, Lima-Brito J, Meirinhos J, et al. (2008). Evidence for clonal variation in 'Verdeal-Transmontana' olive using RAPD, ISSR and SSR markers. J. Hort. Sci. Biotechnol. 83: 395-400.

Mendilcioglu K (2001). Olive Growing Techniques. Publication No. 36. Ege University, Bornova.

Muzzalupo I, Lombardo N, Musacchio A, Noce ME, et al. (2006). DNA sequence analysis of microsatellite markers enhances their efficiency for germplasm management in an Italian olive collection. J. Am. Soc. Hortic. Sci. 131: 352-359.

Rohlf FJ (2004). NTSYS-pc Numerical Taxonomy and Multivariate Analysis System. Version 2.11V. Exeter software, Setauket.

Sanz-Cortés F, Parfitt DE, Romero C, Struss D, et al. (2003). Intraspecific olive diversity assessed with AFLP. Plant Breed. 122: 173-177.

Sarri V, Baldoni L, Porceddu A, Cultrera NG, et al. (2006). Microsatellite markers are powerful tools for discriminating among olive cultivars and assigning them to geographically defined populations. Genome 49: 1606-1615.

Sefc KM, Lopes MS, Mendonca D, Dos Santos MR, et al. (2000). Identification of microsatellite loci in olive (Olea europaea) and their characaterization in Italian and Iberian olive trees. Mol. Ecol. 9: 1171-1173.

Sensi E, Vignani R, Scali M, Masi E, et al. (2003). DNA fingerprinting and genetic relatedness among cultivated varieties of Olea europaea L. estimated by AFLP analysis. Sci. Horticulturae 97: 379-388.

Sneath PHA and Sokal RR (1973). Numerical Taxonomy: The Principles and Practice of Numerical Classification. Freeman, San Francisco.

Ünal K and Nergiz C (2003). The effect of table olive preparing methods and storage on the composition and nutritive value of olives. Grasas Aceites 54: 71-76.

Yalcinkaya E, Kaynas N, Sutcu AR and Fidan AE (2000). Gemlik Zeytininde Klon Seleksiyonu Yoluyla Alternans Göstermeyen, Üstün Özellikteki Tiplerin Belirlenmesi Üzerine Arastirmalar. In: Proceedings of the 1st Symposium on Olive Growing of Turkey, Bursa, 372-381. 